\title{
Corporate Social Responsibility Reporting Practices in the Banking Sector of Nepal
}

\author{
Kshitiz Upadhyay-Dhungel \\ Think Tank Foundation, Jorpati, Nepal \\ Email: kistiz2008@gmail.com; ttfnepal@gmail.com \\ Amar Dhungel \\ Audit Assistant, CSC \& Co., Kathmandu Nepal
}

\begin{abstract}
Financial institutions not only influence the profit/loss of its shareholders but also drive the economy of the whole nation. So it should be concerned about its social obligation and responsibilities. Social responsibility refers to the obligation of a firm, beyond that required by law or economics, to pursue long-term goals that are good for society. The idea that firms, corporations, and other organizations have social responsibilities leads to the development of the concept labeled as "Corporate Social Responsibility (CSR)" and has evoked widespread interests and concerns both in business and among academicians. Banking sector is under massive pressure from its shareholders, investors, media, as well as its customers to carry out business in a socially responsible and ethical manner. This descriptive study attempts to analyze CSR reporting practices in banking sector of Nepal. For the purpose, ten commercial banks and 4 development banks were selected randomly and their website was scanned to collect data developing a Report Sheet. The total CSR reports were outlined and categorized into different groups. Later on quantitative analysis was also performed and presented using suitable statistical techniques.
\end{abstract}

This study found that CSR is not mandatory in Nepal and all the banks that have made the disclosure of social responsibility have done it in voluntary basis. Among the disclosed information education, training, and welfare of underprivileged; arts/heritage and culture protection; contribution to associations, clubs and other organizations; contributions for healthcare and environment; etc were the most commonly reported CSR activities. Child and women developments, religious activity, games and sports activities, blood donations were also among the thrust area for CSR reporting. The disclosures were mostly qualitative with exception of donation and sponsorship amounts. The analysis also shows that most of the Nepalese banks, especially public sector banks, do not mention CSR explicitly on their websites.

This study strongly recommends the development of uniform standards and framework for reporting of CSR activities, which could be applied to compare it at national levels with other banks and/or industries as well as for the international comparisons. Banks can play a leading role to establish the CSR concepts in Nepalese business and corporations. It is expected that this paper will stimulate more studies in this direction. More such studies should be conducted, especially on 
developing countries like Nepal, where CSR is at an infant stage of development. In addition to tracing the trend of social disclosure, impacts of social and economic development on CSR practices, there is also a need to develop a framework for CSR reporting.

Keywords: Social Responsibilities, Corporate Sector, Economic Development, Education and Training, Banks

\section{Introduction and background of the study}

Ethics, moral values, and social responsibility are key challenges among many, faced by different business managements in recent years. Notably, the Nepalese financial services industry has faced criticism over a number of issues relating to the management and delivery of its products and services. Financial institution not only influences the profit/loss of its shareholders but drives the economy of whole nations. So it should have more concern about its social obligation and responsibilities. Social responsibility refers to the obligation of a firm, beyond that required by law or economics, to pursue long-term goals that are good for society (Ioanna et al., 2005). The idea that firms, corporation and other organizations have social responsibilities leads to the development of the concept labeled as CSR and has evoked widespread interests and concerns both in business and among academicians (Vaaland et al., 2008).

World Business Council for Sustainable Development (2001) explained CSR as the commitment of business to contribute towards sustainable economic development, working with employees, their families and the local communities. Welzel (2006) expresses CSR as an accepted and effective concept for business to help solve societal problems and at the same time strengthen their core business activities. According to European Commission of 2001, CSR is day by day developing into a tool for societal cooperation and the active shaping of globalization.

Now a day, banking sector is under massive pressure from its shareholders, investors, media, as well as its customers to carry out business in a responsible and ethical manner. Likewise, international organization as World Bank also frequently exert pressures on banks to analyze social and environmental risk involved in projects to be financed. In addition to this, several researchers also have shown that CSR practices of an organization have significant impact on its reputation and resultant profitability of the organization (Maignan \& Fereel, 2001; Maignan \& Fereel, 2004; Senthikumar et al., 2011).

The past three decades have witnessed the emergence of CSR as a field of research study and a framework for the role of business corporations and financial institutions in society. In fact there is availability of very limited research work in the context of implementation of CSR practices in context of developing nations. It is even rare in Nepalese context. In this reference, the present study plans and attempts to analyze CSR reporting with special reference to banking sector in Nepal. 


\section{Research questions}

Main purpose of the study is to find the CSR reporting practices in Nepal. Thus following were the research questions developed for the study:

1. What is the present status of CSR in Nepalese banks?

2. What is the status of reporting of CSR in Nepalese banks?

3. What are the thrust areas on reported cases of CSR in Nepalese banks?

\section{Literature Review}

CSR is a generalized concept of what constitutes "good" or "desirable" business behavior. It relates to what can be judged "morally" or "ethically" good (Vaaland et al., 2008). It is often linked with the term ethical behavior, sustainable development, corporate governance, good governance, the environment, and to philanthropic ideas (Ioanna et al., 2005). It emphasizes the intimacy of the relationship between the corporation and society (Karjee, 2011).

The concept of CSR is not new one but its focus changes from time to time according to changing needs of business and social needs. In 1960, CSR emerged out from an attempt to link business with society. The underlying expectation in this era was to apply the resources in a socially responsible manner, that is, the promotion of social welfare along with the economic development (Sharma, 2011). Later on to enlarge the periphery of CSR from pure economical boundaries, in 1970 's CSR was identified as the compliance to the business ethics. The concept was to maximize profit without deception or fraud to any party and lying within the rules and regulation of the state (Sharma, 2011). In 1973, Davis described CSR as firm's consideration and response to different issues which may rest beyond the narrower territories of economic, technical and legal requirements of the firm state (Douglas et al., 2004). McGuire (1963) took the view: The idea of social responsibility supposes that the corporation has not only economic and legal obligations, but also certain responsibilities to society which extend beyond these obligations. Later, Sethi (1975) suggested that these extra responsibilities involved: bringing corporate behavior up to a level where it is congruent with the prevailing social norms, values, and expectations.

Naylor (1999) defines social responsibility as: the obligation of managers to choose and act in ways that benefit both the interests of the organization and those of society as a whole. CSR implies that an organization is responsible for its wider impact on society (Frankental, 2001). According to Patil-Dake (2011), CSR is the deliberate inclusion of public interest into corporate decision-making and the honoring of a triple bottom line: People, Planet, and Profit. Juholin (2004) in short and sweet way describes CSR as simple legal compliance and as conducting business with a high regard for morality.

From the beginning of this new millennium, CSR has been in great focus of business and management researches and academia. The expansive concept of CSR is not universally accepted. Nor is it anywhere required by legislation. Yet a growing number of voices in contemporary society, especially in the more prosperous economies of the world, are calling on business to contribute more than at present to general public and social welfare (Robin, 2008). 
Several researches were carried out in last few decades to define CSR, to develop CSR-framework, classifying CSR practices, CSR and good governance, CSR and sustainable developments, impact of CSR on business, strategies and ways in promoting and implementing CSR, role of states on implementing it and so on (McGuire, 1963; Davis, 1973; Sethi, 1975; Naylor, 1999; Lewicka-Strzalecka, 2006; Morhardt, 2009; Sharma, 2011). Longo et al. (2005) took stakeholder perspective to examine the CSR obligations and contributions of firms. Some studies like Quazi and Brien (2000) and Deniz and Suarez (2005) have made distinctions among classical, socio-economic, philanthropic, and modern views of CSR. In short during this period several researches in early part of this millennium were against CSR. Opponents of CSR argue that the business of business is making money and that a company's only responsibility is to maximize profits for its shareholders. Why then, are so many organizations seeking a socially responsible reputation and publicizing their activities (Douglas et al., 2004)? In recent years, researches on CSR also focuses on the debate of making the CSR mandatory by law or should it be made voluntary (Galbreath, 2006; Robin, 2008). Robins pointed out that CSR should be popularized but not be imposed. For Ford (2003), a good company delivers excellent products and services, and a great company does all that and strives to make the world a better place. This is about being socially responsible citizen by any business organization. This attitude favors the fact that if any organization realizes its responsibility, neither the state has to use its power to make it mandatory, nor the organization feels burden about it. In 2008, Higgins studied different CSR strategies and found out that CSR initiatives that are voluntary and strategic, as opposed to coerced and/or non-strategic, generate the most sustainable mutual benefit to the firm itself and its social beneficiaries (Higgins, 2008).

There is consensus among the proponents favoring the concept of CSR that the concept of CSR recognizes an organization's commitment to operate in a socially responsible manner. It takes into consideration the social and environmental implications of corporate financial decisions. Growing complexities of business, increasing concern for sustainable development, need for stewardship of natural resources and call for enhanced transparency have heightened the inclination towards integration of CSR principles in the corporate activities (Welzel, 2006).

Lantos (2001, 2002) suggests three archetypes of CSRs namely, ethical, altruistic, and strategic. Ethical CSR constitutes a minimum level of responsibility to society, and implies that the company avoids harm or social injuries even to exceed the formal legal duties, if necessary. Altruistic CSR corresponds with Carroll's (2000) philanthropic responsibilities and aims at contributing to the good of various social stakeholders, even if the cost of those activities sacrifices company profit. Strategic CSR implies fulfilling philanthropic responsibility, but with the company's benefit in terms of positive publicity and goodwill as core driver. Activities sustaining strategic CSR are assumed to improve corporate image and increase motivation and loyalty primarily among employees and customers, but also others such as suppliers and retailers (Lantos, 2002). In a marketing context, strategic CSR is particularly relevant because of its focus on company benefits in relation to stakeholder groups 
(like customers). Vaaland and Heide (2005) from various literatures observed that CSR emphasis is on: first, corporate benefit; second, stakeholders; third, concern for both responsible and irresponsible acts; and fourth, ethical, environmental, and social phenomena.

Different Nation has their own way to look at CSR. The UK has a Minister for CSR. The Department of Trade and Industry has assured in the companies law so that environmental and social performance have to be reported alongside financial performance (Douglas et al., 2004). In the USA, the focus for CSR is driven by the context in which minimal legislative control on business is considered preferable, and thus corporations need to use internal policy to "police themselves" and external communications to demonstrate their CSR. In addition, the USA has a long standing tradition of philanthropy because the state does not provide the extensive social services available to all citizens. In contrast, Denmark follows the European state model of heavy government control on businesses and the social model of being the central social service provider (Kampf, 2007). In Malaysia, all publicly listed companies are required to disclose their CSR activities in their annual reports beginning from the financial year ending December 31, 2007. The contents of CSR disclosure, however, remain voluntary (Othman, 2011). Wildes (2008) mentioned in his paper the CSR concept adopted in different country of the world using the citation Holme and Watts (2000) which is mentioned in following table (Table 1). 
Table 1: Concept of CSR in different countries

Brazil

CSR is about commitment to strive for the best economic development for the community, to respect workers and build their capacities, to protect the environment and to help create frameworks where ethical business can prosper

Argentina CSR is about a corporation's ability to respond to social challenges. It starts with developing good relations with neighbors. Companies should make a strong commitment to education, worker rights, capacity building, and job security. CSR is stimulating the economic development of a community

Ghana CSR is about capacity building for sustainable livelihoods. It respects cultural differences and finds the business opportunities in building the skills of employees, the community and the government

The Netherlands CSR is about making a leadership commitment to core values and recognizing local and cultural differences when implementing global policies. It's about companies endorsing the UN Convention on Human Rights and the ILO Rights at Work

Thailand $\quad$ CSR must be locally relevant and meaningful only if backed up action

Taiwan

CSR is the contribution to the development of natural and human capital, in addition to just making a profit

The Philippines $\quad$ CSR is about business giving back to society

In Thailand, people said it should try to capture: the concept that the bigger the company, the greater the obligation; the importance of environmental mitigation and prevention; the need for transparency; the importance of consumer protection; awareness of and change in people's attitudes towards the environment; and the relevance of youth and gender issues

[Source: Holme and Watts (2000) as cited in Wildes, (2008)]

\section{CSR in banking sector (global context)}

Former UN Secretary-General Kofi Annan once stated, "The stark reality is that most poor people in the world still lack access to sustainable financial services, whether it is savings, credit or insurance. The great challenge before us is to address the constraints that exclude people from full participation in the financial sector. Together, we can and must build inclusive financial sectors that help people improve their lives" (Patil, 2011).

Financial services firms like banks recognize that they need to develop strategies which would show that they take account of wider societal concerns which arise from their business activity. As such, over time the CSR practice of banks is expected to contribute to the development of evolutionary trends in the industry (Decker, 2004). Banks have realized that the concept of CSR definitely impacts on their operating environment and has significant consequences for their 
performances and survival (Decker, 2004; Zappi, 2007; Joseph, 2008). Joseph (2008) emphasize that banking organizations is one of the most sensitive sector to the impact of CSR. This is because, this sector is subject to a more diverse and complex publics than most other sectors of the economy. A bank has a corporate social obligation to satisfy all these complex publics:

A bank undertakes to maximize profit for shareholders who contributed funds to set it up. It must maintain optimal liquidity to meet depositors demand. It is obliged to satisfy the legitimate deficit sector demand for credits. The bank must comply with regulators' requirements to continue in business. Above all, for the bank to be seen as a good corporate citizen, it has to contribute to the maximum development of the economy as well as satisfy its immediate community (Nwankwo, 1991: Pp. 26, as cited on Joseph, 2008).

The complexities and indispensability of these interrelationships mentioned in above paragraph have made CSR and corporate existence of banks inseparable. The banking sector is the pivot of socio-economic development of any economy. Banks need to be socially responsible to be able to build their "reputational capital" which enables them to attract high-quality employees, enable them to charge higher fees, negotiate better deals, expand customer base, attract more investors, and win public trust (Joseph, 2008).

With globalization and development of multinational companies, the structure of the banking public may be far more complex than can be readily predicted. Moreover, the dynamism and complexities of modern society continues to change the composition and intricacies of CSR requirements of the banking industry. In financial sector several international initiatives like United Nations Environment Programme Finance Initiative, Global Reporting Initiative, Equator Principles and Collavecchio Declaration on Financial Institutions, etc are there to ensure the adoption of CSR practices in normal business operations. Likewise, international organization such as the World Bank also frequently exert pressures on banks to analyze social and environmental risk involved in projects to be financed (Sharma, 2011). These initiatives have favorably tuned up developed countries to behave in a socially responsible manner. However in developing nations, there is a dearth of deliberate and effective actions (Othman et al., 2011).

Most of the researches, related to CSR in banking sector include the impact of CSR on customer satisfaction, marketing and overall banking sector. Few researchers have concluded about the positive impacts of CSR initiatives in the banking sector. Lemke (1987) reports that a Massachusetts bank found to be highly successful in promoting new accounts (138 accounts worth $\$ 11$ million) by assisting a campaign to revive the dying out animal species with donations made to the World Wildlife Fund. Collective impact of consumers on CSR programs are reported in few other studies (Sharma, 2011). Senthikumar (2011) reported that the CSR dimension is most influential factor to the mediating factor Customer Satisfaction $(0.443)$ which means CSR strongly and positively influences customer satisfaction toward banking service quality. Sharma (2011) reported the CSR practices of banking sector in India. The study reveals that there are very few banks who report their CSR 
practices in their websites. This practice is at primitive phase in India as there is no mandatory rule to report CSR. There is less concern about this issue. Education and employments were the major thrust area of CSR reporting for private sector banks whereas Indian public sector banks most actively participate for alleviation of regional imbalances through initiating various activities for promotion of rural development.

\section{CSR Researches in Nepalese Context}

There are very few researches, almost nil related to CSR practices in Nepal. The report titled "Corporate social responsibility in Nepal: A chance for peace and prosperity?" by Welzel in 2006 is a single reported study on CSR in Nepal found through Google Search. "Guiding tools for Nepalese business corporate social responsibility" published by Lotus Opportunities and Action Aid is the only next material about CSR in Nepal. However, some banks have started reporting their CSR activities in their website from last few years. There is not a single research paper related to CSR activity in the banking sector of Nepal. Hence, this study could probably be the pioneer work in this regard.

\section{Research Methodology}

The research is an exploratory type in nature. It is descriptive and analytical study in which the CSR reporting by banking sector in Nepal has been explored.

Measurement of the quantity of CSR disclosure can take many forms, including the number of characters, words, sentences, pages or proportion of pages covering the various categories of social disclosure. Various past studies have utilized and justified each of the above methods of measurement (Unerman, 2000). However in this study, the reporting under CSR heading was only taken as CSR report. This is one of the the way used in CSR practices studies (Sharma, 2011).

The pages in website were scanned and data were collected developing a frame or report sheet. The total reports were outlined first, categorized into different groups. Later on the reporting was re-grouped into broader groups.

\section{Data Collection}

For this research, ten Commercial Banks (CBs) and four Development Banks (DBs) were selected randomly. CBs were selected from a list of members of Nepal Bankers Association in 2011. The list was taken from the Banking Journal. DBs were randomly selected from the list in the website of Nepal Rastra Bank, NRB (http://bfr.nrb.org.np/List_Banks_n_Non_Banks.php). First, the DB with paid up capital of more than 400 million were selected and from this list four DBs were randomly selected. After that, their websites (respective CBs and DBs) were visited and data was collected from the websites of the selected banks. Other published materials, various books, magazines, journals, etc were also reviewed. Secondary information was also obtained from newspaper and other relevant publications. 


\section{Data Analysis}

The data were analyzed using standard method used in qualitative data analysis. Quantitative analysis was performed and presented using suitable statistical techniques.

\section{Result and Discussion}

A total of 14 banks and financial institutions (BFIs, Banks in short) were selected for the study. Out of 14 , ten banks under study have reported at least a single CSR activity in their websites. The types of banks and number of CSR reporting cases are presented in Table (2). CBs include both the public (having full/partial government equity) and private banks. In this study, there are three public sector $\mathrm{CBs}$, seven private sector $\mathrm{CBs}$, and four DBs.

Table 2: CSR reporting among different types of Banks under study

\begin{tabular}{llr}
\hline Type of Banks & Total Number of Banks & CSR Reporting (\%) \\
\hline Public CBs & 3 & $1(33.33 \%)$ \\
Private CBs & 7 & $6(85.71 \%)$ \\
DBs & 4 & $3(75 \%)$ \\
Total & 14 & $10(71.43 \%)$ \\
\hline
\end{tabular}

\section{Present status of CSR reporting by Banks in Nepal}

CSR is not mandatory in Nepal and all the banks that have made its disclosure have done it in voluntary basis. Three banks have separate page for CSR reporting on their websites. One of the banks has mentioned:

"...CSR for us means embracing responsibility for the impact of our activities on the environment, consumers, employees, communities, stakeholders and all other members of the public sphere thereby managing our business responsibly and sensibly for long-term sustainable banking..."

This shows that few of the banks have already taken CSR practices seriously. But it seems that they have not developed proper strategies and planning regarding it. They need training and support. Proper framework need to be designed.

Out of three public sector CBs only one have reported their CSR activity in their website. Out of seven private sector banks, six have reported their CSR activity and out of four DBs, three has reported at least a single case of CSR activities in their respective websites. Analysis of the data showed that most of the reported CSR events look like charity and donation. Except very few events by very few banks, most of the CSR activities are in adhoc. Whosoever comes and demands for the support they give donation. For instance, in a year under consideration, they are providing charity/funds (for example to support games, support any organization, support educational activities, and so on) to one and next year to another. Most of them are not continuing the same support each year. They don't have proper planning and allocation of budget for CSR. They lack proper strategies and field for CSR. Strategy, which is the core part of CSR (Welzel, 2006), is missing. When we compare the activities that these Banks has reported as CSR with the available literature related to CSR, we can conclude that banks seem confused between 
Charity and CSR. These activities are praiseworthy and should not be abandoned but they are not CSR in true sense (as per concept and definition). The motivation behind these contributions (in cash or in kind) is mostly a humanitarian one, resulting from a feeling that "it is just the right thing to do". This attitude can be noticed quite often particularly in Nepal where religion plays an important role in society and charity is an important element of these religions. CSR starts where philanthropy ends and is a strategic concept dealing with the business activities itself that will eventually bring benefits to both company and society. CSR is not about how a company spends its income but rather about how it generates that income (Sharma, 2011; Karjee, 2011).

\section{Core thrust areas for reported CSR activities}

Major areas of CSR intervention by all types of banks is shown in Table (3). The most common CSR intervention is on education and training (64.29\%) and welfare of underprivileged groups (64.29\%). In a study done in Singapore among 33 companies including banking industry, human resource development was the most focused area in CSR activities (Tsang, 1998). In the Nepalese context, the focus was also on education and training, however, most of the CSR activities were in the form of donations to build a school building and its improvement. The underprivileged groups who are receiving funds or donations are to orphanage, old age homes, physically disabled, scheduled casts, etc. Unlike the CSR reporting of Indian banks (Sharma 2011), more than $40 \%$ of banks in Nepal intervene in arts/heritage/culture. Nepalese people values their arts, heritages, and cultural things than anything else. This is probably well understood by banks in Nepal, so this sector has gained more priorities in their CSR activities. Indian public sector banks most actively participate for alleviation of regional imbalances through initiating various activities for promotion of rural development as their CSR activities. Besides it, they primarily focus on women empowerment and bringing gender equity (Sharma, 2011), whereas in this study only a single bank has invested on rural development and about $29 \%$ of banks are found to be working for women and child. In Nepalese case, the private sector banks are struggling even to have their branches in rural area. Only the public sector banks have reached to the remote rural area in Nepal. 
Table 3: Major areas of CSR intervention by banks in Nepal, $\mathrm{N}=14$ (for reported CSR activities)

\begin{tabular}{lll}
\hline Area of CSR intervention & Number of Banks & Percentage \\
\hline Education/Training & 9 & $64.29 \%$ \\
Welfare of underprivileged & 9 & $64.29 \%$ \\
Arts/Heritage/Culture & 6 & $42.86 \%$ \\
Associations/Clubs/Trusts/Organizations & 6 & $42.86 \%$ \\
Health care & 6 & $42.86 \%$ \\
Environment & 5 & $35.71 \%$ \\
Child/Women development & 4 & $28.57 \%$ \\
Religious/Spiritual & 4 & $28.57 \%$ \\
Games/Sports & 3 & $21.43 \%$ \\
Natural and other calamities & 3 & $21.43 \%$ \\
Blood donation & 3 & $21.43 \%$ \\
Rural development & 1 & $7.14 \%$ \\
Others & 6 & $42.86 \%$ \\
\hline
\end{tabular}

Core thrust areas among the reported cases of CSR of CBs in Nepal are depicted in Figure (1. Among the disclosed information, human resource development got the widest coverage, and was followed by community involvement and the environment in a study done in thirty-three companies including banks in Singapore (Tsang, 1998). In this study also these three areas are among the priorities but not on the topmost priorities for reporting CSR activities. Health sector is in priority of $36 \%$ banks and environment is in priorities of $46 \%$ banks. 
Figure 1: Chart showing the major thrust areas for reported CSR activities among CBs in Nepal $(\mathrm{N}=7)$

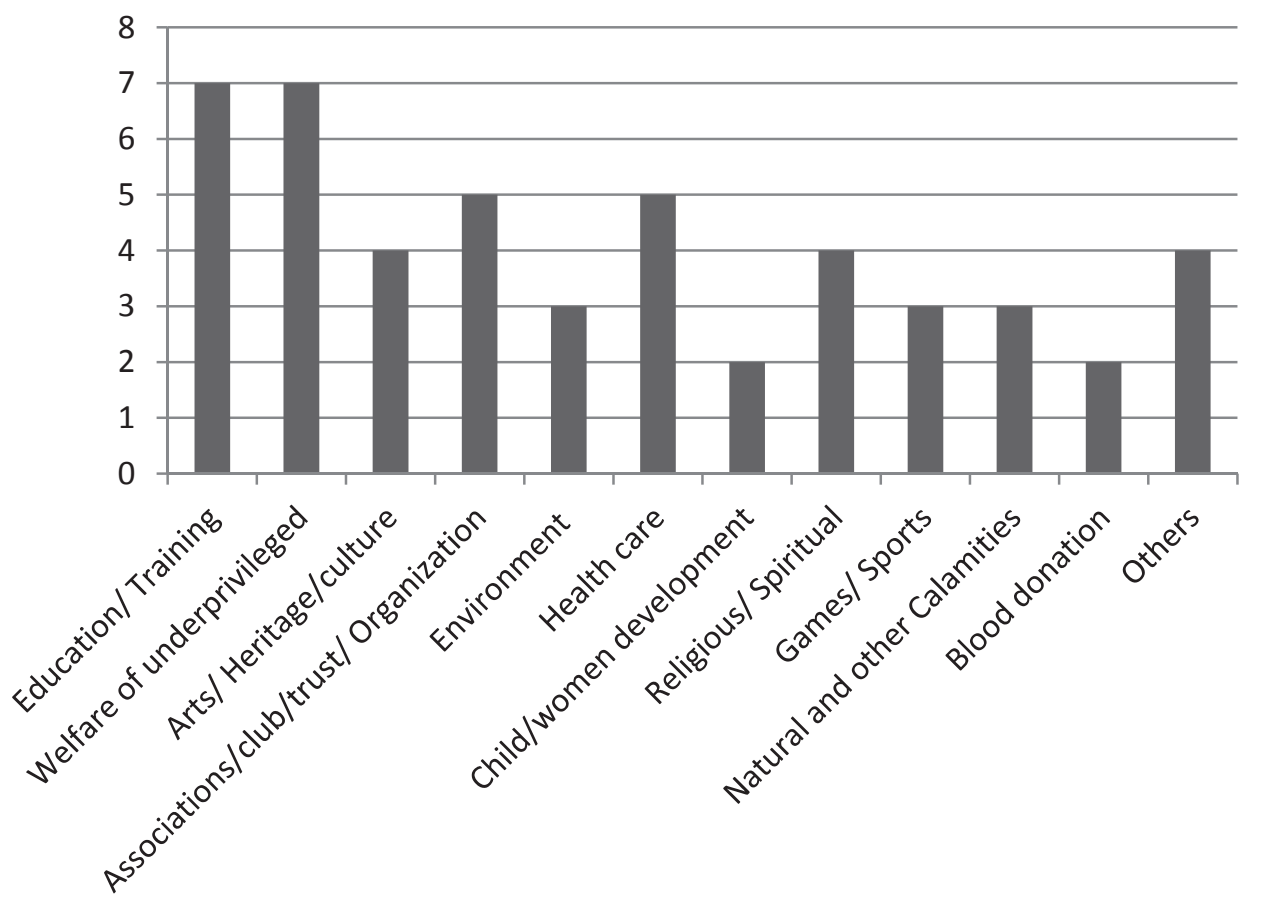

It is clear from the figure that the CSR practices in Banks of Nepal represents a wide range of activities including education and training, welfare of underprivileged, arts/heritage/culture protection, support to associations/clubs/other organizations, healthcare, environment, and so on. CSR activities of banks also involve child and women developments activities, religious activities, games and sports, blood donations, etc.

It can be observed from Figure (2) that the major areas for reporting CSR activites of DBs in Nepal shows their CSR priroties on environment and child/women developments, which is relatively higher than the CBs. However they seems to be equally reporting the activities in education/training and arts/heritage/culture protection activities. 
Figure 2: Chart showing the major thrust areas for reported CSR activities in DBs in Nepal $(\mathrm{N}=3)$

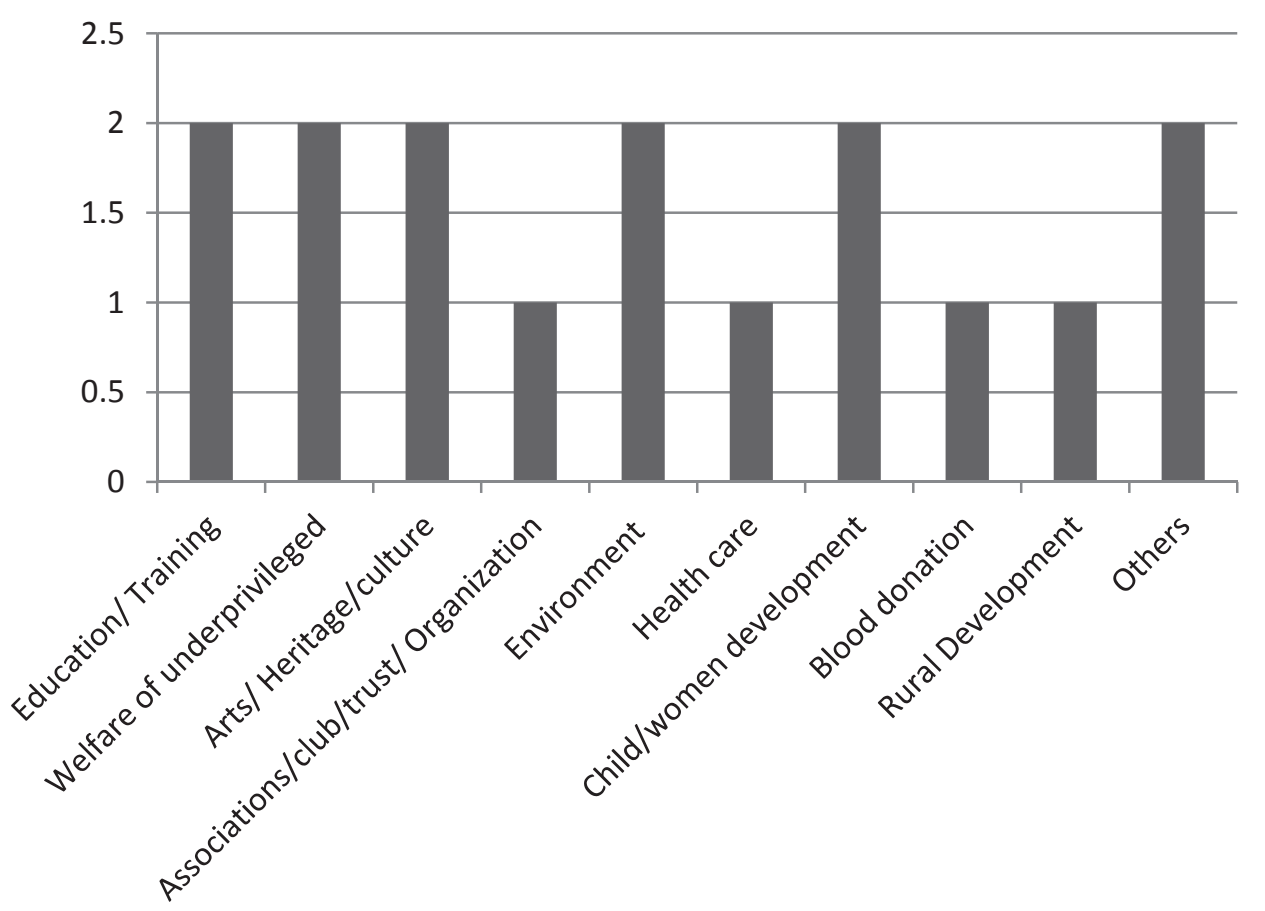

\section{Role of Government in implementing and reporting on CSR practices}

The State should be a significant driver of CSR or at least a supporter of CSR. Welzel (2006) from his pioneer study of CSR in Nepal reported that the Nepalese Government at all levels is absent in this field. He further blames that there are no visible policies in place to enhance CSR and it is very difficult, if not impossible, to meet representatives familiar with the concept. Since CSR is genuinely a concept involving all three actors (government, business, and society) aiming at solving societal problem that affect all three actors some connection to the government should be established. The aim should by no mean be a regulation but a better framework for CSR exercised by companies and civil society organizations (Welzel, 2006). Nepal Rastra Bank (NRB) circular has clearly instructed that the different banks and financial institutions are required to lend a certain percentage of their total outstanding loan and advances under the deprived sector lending. It was also being increased in the recent years (CBs need to lend $5 \%$ by the end). This is a praiseworthy example of CSR promoting initiative taken by the NRB (NRB, 2012). Although, it could be a different topic for debate whether such forced lending are appropriate or not, it showed that NRB has also visualized some societal responsibilities from the banks. Since, the CSR seems to be an important issue of government, the CSR activities of public banks need to be explored too.

\section{CSR reporting by public banks in Nepal}

The result of this study shows that there is almost nil CSR reporting in the websites by all three public banks. Only one bank (Rastriya Banijya Bank, RBB in short) 
among three has mentioned few lines on CSR. Figure (3) shows the thrust areas for reported CSR activities of RBB.

\section{Figure 3: Major thrust areas for reported CSR activities of RBB}

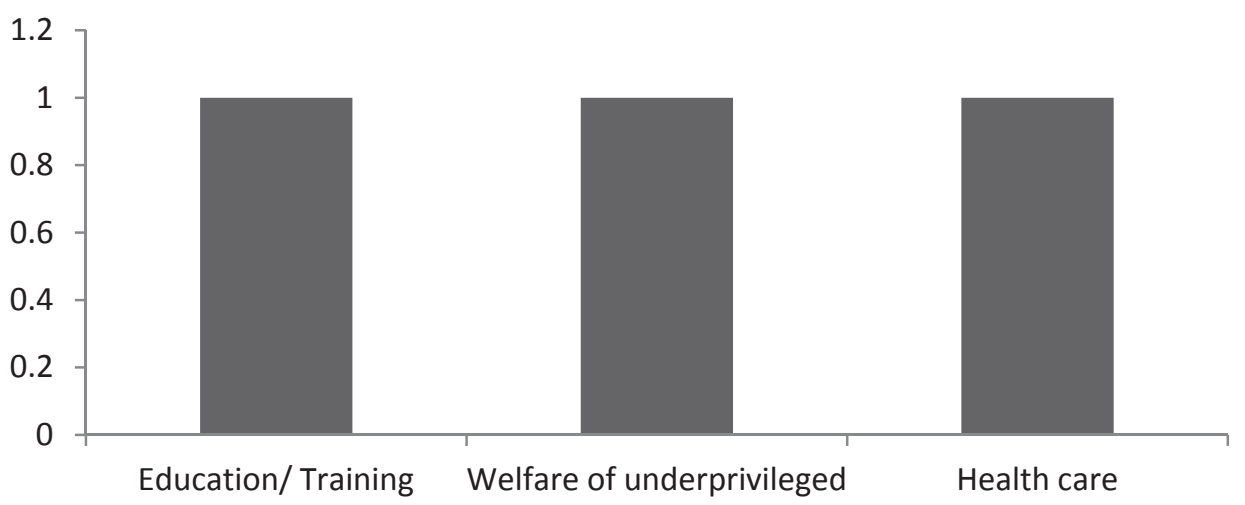

However, the very negligible reporting of CSR activities by public sector banks does not mean that they are not concerned about CSR activities. They all were the initial banks in Nepal and were opened to supply the need of the citizens in Nepal only. The following quotation used in the website of Nepal Bank Ltd. (NBL) proves that they are not far from the CSR activities but they are more concerned about Nepalese people. The quote goes as:

In the absence of any bank in Nepal the economic progress of the country was being hampered and causing inconvenience to the people and therefore with the objective of fulfilling that need by providing service to the people and for the betterment of the country, this law in hereby promulgated for the establishment of the Bank (NBL) and its operation.

Furthermore, the next public $C B$, the Agriculture Development Bank Ltd. (ADBL) in its website mentioned:

"... with the main objective of providing institutional credit for enhancing the production and productivity of the agricultural sector in the country, the ADBL was established in 1968 under the ADBL Act, 1967, as a successor to the Cooperative Bank. The Land Reform Savings Corporation was merged with ADBL in 1973. Subsequent amendments to the Act empowered the bank to extend credit to small farmers under group liability and expand the scope of financing to promote cottage industries. The amendments also permitted the bank to engage in commercial banking activities for the mobilization of domestic resources..."

The above paragraph clearly shows that one of the public sector banks (ADBL) was established just for the development of agriculture sector which is still one of the main sectors for revenue generation and major part of GDP. Later on, the bank started its commercial activities too. Among the three public sector bank in the 
present study, Rastriya Banijya Banks (RBB) has only mentioned something on CSR in their website. Although it has not mentioned anything under CSR heading, it has mentioned following statements on their homepage:

"...the bank is also in the frontline towards fulfilling CSR. The bank has established a fund aimed at helping patient related with kidney ailment and groundwork are underway in course of initiating special campaign in this sector. The bank has been working as a chief administrator in the educational assistance project (run with assistance of World Bank) aimed at assisting poor and diligent students learning at higher secondary and bachelor level..."

Furthermore, the public sector banks in Nepal are the banks that have maximum number of branches throughout Nepal (for example, NBL has 114 branches, RBB has 144 branches, and ADBL has 242 operational network) and serving by providing banking services to the remote and rural areas which the new emerging banks are struggling to achieve. According to the financial projection documents of $A D B L$, it claims that it has the largest rural financial institution and the extensive branch network. They are providing loans in very cheap rate to different agricultural forms and farmers to initiate agricultural business. Even it is true for NBL and RBB. They have invested in different developmental projects of nations and support the government programs to improve the livelihoods of people.

\section{Conclusion and Recommendations}

CSR is not mandatory in Nepal and all the banks that have made the disclosure in voluntary basis. Among the disclosed information education and training; welfare of underprivileged groups; arts, heritage, and culture protection; supporting different associations, clubs, or other such organizations; healthcare; environment; etc were the most commonly reported CSR activities. Child and women developments, religious activity, games and sports activities, blood donations were also among the thrust area for CSR reporting. The disclosures were mostly qualitative with exception of donation and sponsorship amounts. The disclosure seems to be public relation driven in the sense that their presence would enhance a company image.

The analysis also shows that most of the Nepalese banks especially public sector banks do not mention CSR explicitly on their websites. Also, a very few other banks has CSR report page on their websites. There is hardly anything mentioned regarding their CSR practices in most of the websites. However, at no account, it means lack of bank's participation in CSR activities. In fact problem lies with inadequate norms regarding CSR reporting system. For example, ADB and NBL are well known for its social activities but has no clear visible link with any project it has invested on or its support of government programs to improve the livelihoods of people. This study strongly recommends the development of uniform standards and framework for reporting of CSR activities, which could be applied to compare it at national levels with other banks and other industries and with international levels. This will benefit the organization itself since it would be seen as serving the society and not only engaged in profit-making business activities. There is strong necessity of proper guidelines to be formulated by accounting profession and or relevant public bodies to raise the standard of CSR practices. As we are in verge of making 
new Nepal and we are at the stage of need of double digit economical growth and many multinational companies are in pipeline so to make each company socially responsible the concept of CSR needed to be introduced among various companies and Banks can play a leading role to establish the CSR concepts in Nepalese business and corporations.

This study is just a start. It is expected that this paper will stimulate more studies in this direction. More such studies should be conducted, especially on developing countries like Nepal where CSR is at an infant stage of development. In addition to tracing the trend of social disclosure and impacts of social and economical development on CSR practices, there is also a need to develop a proper framework for CSR reporting as well as develop habit for it. It will enhance the reputation of the company itself.

\section{Acknowledgements}

This research was partially funded by Nepal Bankers Association and Banking Promotion committee under NBA/BPC Research Grant Number NBA/BPC RG\#4B.

\section{References}

Carroll, A. B. 2000. The four faces of corporate citizenship. In: Richardson, J. E. (Ed.). Business Ethics 00/01. Dushkin/McGraw-Hill, Guilford: 187-91.

Davis, K. 1973. The case for and against business assumption of social responsibilities. Academy of Management Journal, Volume 16: 312-322.

Decker, O. S. 2004. Corporate social responsibility and structural change in financial services. Managerial Auditing Journal, Volume 19 (6): 712-728.

Deniz, D. M., K. C. Suárez. 2005. Corporate Social Responsibility and Family Business in Spain. Journal of Business Ethics, Volume 56: 27-41.

Douglas A., J. Doris, and B. Johnson. 2004. Corporate social reporting in Irish financial institutions. The TQM Magazine, Volume 16 (6): 387-395.

Ford, W. Jr. 2003. Ford motor company encourages elementary school students to support America's national parks. http://www.ford.com/en/company/NationalParks.htm

Frankental, P. 2001. Corporate social responsibility: A PR invention? Corporate Communications, Volume 6 (1): 18-23.

Ioanna P. D., K. K. Maria, and M. Katsioloudes. 2005. Corporate social responsibility: the way forward? Maybe not! A preliminary study in Cyprus. European Business Review, Volume 17 (3): 263-279.

Joseph K. A. 2008. Corporate social responsibility in Nigerian banking system. Society and Business Review, Volume 3(1): 57-71.

Juholin, E. 2004. For Business or the Good of All? A Finnish Approach to Corporate social responsibility. Corporate Governance, Volume 4 (3): 20-31.

Kampf, C. (2007). CSR WalMart, Maersk and the cultural bounds of representation in corporate web sites. Corporate Communications: An International Journal, Volume 12 (1): 41-57.

Karjee, K., and A. Kumar. 2011. Corporate social responsibility - Path to social responsibility and green practice. Maratha Mandir's Babasaheb Gawde Institute of Management Studies. (Assessed on December 2011). 
Lantos, G. P. 2001. The boundaries of strategic corporate social responsibility. Journal of Consumer Marketing, Volume 18 (7): 595-630.

Lantos, G. P. (2002). The ethicality of altruistic CSR. Journal of Consumer Marketing, Volume 19 (3): 205-30.

Lewicka-Strzalecka, A. 2006. Opportunities and limitations of corporate social responsibility in the postcommunist countries: Polish case. Corporate Governance, Volume 6 (4): 440-448.

Longo, M., M. Mura, and A. Bonoli. 2005. Corporate Social Responsibility and Corporate Performance: The Case of Italian SMEs. Corporate Governance, Volume 5 (4): 28-42.

Maignan I. and O. C. Ferrel. 2001. Corporate citizenship as a marketing instrument: concepts, evidence and research directions. European Journal of Marketing, Volume 35 (3/4): 457-484.

Maignan, I. and O. C. Ferrell. 2004. Corporate social responsibility and marketing: an integrative framework. Journal of Academic Marketing Science, 32 (1): 3-19.

McGuire, J. 1963. Business and Society. McGraw-Hill, New York, NY.

Morhardt, J. E. 2009. Corporate social responsibility and Sustainability Reporting on the internet. Business Strategy and the Environment. DOI: 0.1002/bse.657.

Naylor, J. 1999. Management. Pitman Publishing, London.

NRB. 2012.. Unified Directives - 2069 : Issued by Nepal Rastra Bank to the Licensed Banks and Financial Institutions. Banks and financial institutions regulation department, NRB.

Othman, S., F. Darus, and R. Arshad. 2011. The influence of coercive isomorphism on corporate social responsibility reporting and reputation. Social Responsibility Journal, Volume 7 (1): 118-135.

Patil-Dake, J. 2011. Corporate social responsibility in Indian Banking sector. Maratha Mandir's Babasaheb Gawde Institute Of Management Studies. (Assessed on December, 2012)

Quazi, A. and D. O. Brien. 2000. An Empirical Test of a Cross-National Model of Corporate Social Responsibility. Journal of Business Ethics, Volume 25: 3351.

Robin F. 2008. Why Corporate social responsibility should be popularised but not imposed. Corporate Governance, volume 8 (3): 330-341.

Senthikumar, N., A. Ananth, and A. Arulraj. 2011. Impact of CSR on customer satisfaction in banking service. African Journal of Business Management, Volume 5 (7): 3028-3039.

Sethi, S. P. 1975. Dimensions of corporate social performance: an analytical framework. California Management Review, Volume 17 (3): 58-64.

Sharma, N. 2011. Corporate social responsibility Practices and Corporate social responsibility Reporting in Indian Banking Sector. International Journal of advanced economics and business management, Volume 1 (2): 58-66.

Unerman, J. 2000. Methodological issues - Reflections on quantification in corporate social reporting content analysis. Accounting, Auditing and Accountability Journal, Volume 13 (5): 667-681.

Vaaland, T. I., M. Heide, and K. Gronhaug. 2008. Corporate social responsibility: investigating theory and research in the marketing context. European Journal of Marketing, Volume 42 (9/10): 927-953. 
Welzel, C. 2006. Corporate social responsibility in Nepal: A Chance for Peace and Prosperity? Report based upon a Mission to Nepal.

Wildes, V. J. 2008. How can organizational leaders really lead and serve at the same time? International Journal of Contemporary Hospitality Management, Volume 20 (1): 67-78.

World Business Council for Sustainable Development. 2001. The Business Case for Sustainable Development: Making a Difference Towards the Johannesburg Summit 2002 and Beyond. http://www.wbcsd.org.

Zappi, G. 2007. Corporate responsibility in the Italian banking industry: creating value through listening to stakeholders. Corporate Governance, Volume 7 (4): 471-475.

\section{Websites of different banks in Nepal visited for the study}

- http://www.adbl.gov.np/

- http://www.nepalbank.com.np

- http://www.rbb.com.np

- http://www.nibl.com.np

- http://www.bok.com.np/csr/csr-2011-2012.php

- http://www.kistbank.com/page/our-commitment-to-csr.html

- http://www.nbbl.com.np/general-csr.html

- http://wwww.sunrisebank.com.np/News/sunrise-bank-contributes-to-fellowshipsociety-nepal.html

- http://www.nccbank.com.np/

- http://www.nepalsbi.com.np/

- http://www.cedbl.com/

- http://www.nidc.org.np/

- http://www.ace.com.np/?page=csr\&modee $=$ Contents\&cms_cd $=48$

- http://www.manakamanabank.com/ 